\title{
The influence of photoperiod on growth and sexual function in male and female collared lemmings (Dicrostonyx groenlandicus)
}

\author{
J. F. Hasler,* A. E. Buhl and E. M. Banks \\ Department of Ecology, Ethology and Evolution, \\ University of Illinois, Urbana, Illinois 61801, U.S.A.
}

\begin{abstract}
Summary. The effect of photoperiod on sexual function and growth in weanling male and female collared lemmings (Dicrostonyx groenlandicus) was studied. Males and females maintained in $6 \mathrm{hr}$ light:18 hr dark after weaning were larger at the end of 70 days than their siblings kept in 20L:4D. Males in $6 \mathrm{~L}: 18 \mathrm{D}$ were longer and overall body growth was greater. Males in $6 \mathrm{~L}: 18 \mathrm{D}$ had heavier adrenals but there were no differences in the weights of testes, preputial glands or seminal vesicles or in the mean testosterone levels of the two groups. Females in 6L:18D had heavier preputial glands than the 20L:4D females. There were no differences between the two groups in uterine, ovarian or adrenal weights or in the number or mean size of atretic or healthy Graafian follicles. Adult males kept in 6L:18D increased more in body weight than those in $20 \mathrm{~L}: 4 \mathrm{D}$, but there was no detectable influence of the short photoperiod on reproductive function.
\end{abstract}

\section{Introduction}

The collared lemming, Dicrostonyx groenlandicus, is a microtine rodent which inhabits the arctic tundra from Greeniand west to Alaska (Hall \& Kelson, 1959), and has mainly been studied because of its population cycles (Shelford, 1943; Krebs, 1964; Brooks, 1970). As in other microtines the age at sexual maturity varies seasonally and in accordance with changes in population density (Kalela, 1957; Krebs, 1964; Keller \& Krebs, 1970; Christian, 1971). Microtine rodents are shortlived animals with high annual 'turn-over' rates approaching $100 \%$ (Christian, 1971) and thus the rate of recruitment of juveniles into the breeding population can have a potentially large effect on population dynamics. Field studies of sexual maturity are of limited value in small rodents because of the difficulty in determining the age of animals accurately. In addition, individual environmental factors cannot be controlled and their influence can be determined only circumstantially.

There is some indication that lemmings breed during some winters but not others (Krebs, 1964; MacLean, Fitzgerald \& Pitelka, 1974). Captive pairs produced fewer young when maintained in a photoperiod of $6 \mathrm{hr}$ light: $18 \mathrm{hr}$ dark (6L:18D) than pairs maintained in 20L:4D (Hasler \& Banks, 1975a).

This study was therefore designed to determine (1) what effects short and long photoperiods had on sexual function and growth in weanling male and female collared lemmings, and (2) whether a short photoperiod influenced the reproductive state of adult males.

\section{Materials and Methods}

The lemmings used were laboratory bred descendants of animals trapped near Fort Churchill, Manitoba, in 1967. Laboratory rabbit chow (Purina, No. 5321) and water were available continu-

\footnotetext{
* Present address: Animal Reproduction Laboratory, Colorado State University, Fort Collins, Colorado 80523,
} U.S.A. 
ously. The stock animals were kept in a photoperiod of $18 \mathrm{~L}: 6 \mathrm{D}$ at a temperature of $12 \pm 3^{\circ} \mathrm{C}$. Photoperiod between sunrise and sunset at the latitude of Fort Churchill ranges from a minimum of approximately $6 \frac{1}{2} \mathrm{hr}$ in winter to a maximum of approximately $18 \frac{1}{2} \mathrm{hr}$ in summer (U.S. Naval Observatory, 1973).

\section{Experiment 1}

Young lemmings were weaned at 19 days of age. Between 19-25 days, 25 pairs of littermate males and 25 pairs of littermate females were weighed to the nearest $0.1 \mathrm{~g}$ and allocated so that one animal from each sibling pair was placed either on a short photoperiod (6L:18D) or a long photoperiod (20L:4D). Each lemming was housed individually in a plastic cage measuring $28 \times 17 \times 12 \mathrm{~cm}$ with a hardware cloth top. The light periods were provided by $40 \mathrm{~W}$ white fluorescent lamps in two adjacent rooms with a common ventilation system. Light intensity on the cage racks ranged from $5 \cdot 0-10.0 \mathrm{~cd} \mathrm{~m}^{-2}$. Readings were taken with a Honeywell $1^{\circ} / 21^{\circ}$ meter on the incident illumination reflected from a Kodak neutral test card. Temperature and diet were similar to those for the breeding colony. The animals were maintained in the experimental photoperiods for 10 weeks. At the end of 10 weeks the females were killed by cervical dislocation, weighed and fixed in acetic-formol-alcohol (AFA) for $48 \mathrm{hr}$ and stored in $70 \%$ ethanol. Later, ovaries, uteri, preputial and adrenal glands were dissected, cleaned of fat, blotted on paper and weighed to the nearest $0.1 \mathrm{mg}$. One ovary from each female was embedded in paraffin wax, serially sectioned at $7 \mu \mathrm{m}$ and stained with haematoxylin and eosin. All healthy and atretic Graafian follicles more than $350 \mu \mathrm{m}$ in diameter were counted and their diameters measured with an optical micrometer. Follicles were classified as atretic if they possessed pyknotic granulosa cells or a degenerating ovum.

At the end of 10 weeks the males were anaesthetized with Metofane inhalant (Pitman-Moore), weighed to the nearest $0 \cdot 1 \mathrm{~g}$, and 1-2 ml of blood was obtained by direct heart puncture with a heparinized syringe. The males were then killed by cervical dislocation. The blood was centrifuged and the plasma withdrawn and stored at $0^{\circ} \mathrm{C}$ until radioimmunoassay for testosterone. Males were measured to the nearest $0 \cdot 1 \mathrm{~mm}$ from the tip of the nose to the distal end of the tail. Testes, seminal vesicles, preputial and adrenal glands and the right epididymis were dissected and fixed in AFA. After storage in $70 \%$ ethanol, the organs were weighed to the nearest $0 \cdot 1 \mathrm{mg}$. The right or left testis and the right cauda epididymidis from each male were histologically prepared as described above and examined for spermatogenic activity and the presence of spermatozoa. The male carcases were eviscerated, weighed again, sealed in a plastic bag and frozen for body composition determination. Water content of the carcases was determined by freeze drying and reweighing. The carcases were then extracted for $48 \mathrm{hr}$ in petroleum ether to determine lipid content. Carcases were heated to ashes for $48 \mathrm{hr}$ in a $300^{\circ} \mathrm{C}$ oven and the ash weights determined.

\section{Experiment 2}

Twenty-four mature males, 4-12 months of age, were weighed and randomly allocated into two groups. A heparinized blood sample of approximately $1.5 \mathrm{ml}$ was obtained by heart puncture from each male. Each group of individually caged males was maintained on a photoperiod of $6 \mathrm{~L}: 18 \mathrm{D}$ or 20L:4D for 10 weeks. At the end of 10 weeks the males were anaesthetized and another blood sample was obtained. Testosterone concentrations in the blood samples were determined by radioimmunoassay. The testes and right epididymis from the males kept in $6 \mathrm{~L}: 18 \mathrm{D}$ were fixed and prepared histologically as described above.

\section{Radioimmunoassay of testosterone}

Plasma testosterone levels were determined with a radioimmunoassay technique previously described by Falvo, Buhl \& Nalbandov (1974). Each sample was assayed in duplicate. Plasma volumes of 20,50 or $200 \mu \mathrm{l}$ were used for each sample, depending on the testosterone content of the sample. Samples from a pool of lemming plasma included in each assay $(n=3)$ contained $277 \pm 4 \mathrm{pg}$ 
(S.E.M.) testosterone. The smallest amount of testosterone which was repeatedly distinguishable from zero was $12 \mathrm{pg}$. Seven $100 \mu \mathrm{l}$ samples of plasma from castrated males contained undetectable quantities of testosterone. The amount of testosterone recoverable from $100 \mu \mathrm{l}$ samples of castrated male plasma to which 31,62 or $125 \mathrm{pg}$ testosterone had been added was $32 \pm 4(n=3), 63 \pm 4(n=5)$ and $106 \pm 15 \mathrm{pg}(n=2)$. These values indicate the precision and sensitivity of the assay.

The specificity of the technique and the antibody were tested by determining the ability of various steroids to compete with testosterone in binding to the antiserum (Falvo et al., 1974). Competition was detected only for dihydrotestosterone in physiological quantities. To determine whether dihydrotestosterone or other substances present in male lemming plasma interfered with the measurement of testosterone, Sephadex LH-20 chromatography was performed on pools of plasma from the two weanling male groups (Exp. 1). The amount of testosterone in the chromatographed pooled sample from males kept in $6 \mathrm{~L}: 18 \mathrm{D}$ was $88.6 \%$ of that in the unchromatographed sample. For the plasma from males kept in $20 \mathrm{~L}: 4 \mathrm{D}$, the value was $93.1 \%$ of that in the unchromatographed sample. No testosterone was detectable in the dihydrotestosterone fraction of the chromatographed sample. These data indicate that this assay can be used to measure testosterone in lemming plasma without chromatography.

\section{Results}

\section{Experiment 1}

At the end of the 10-week test period, both siblings were still alive in 16 of 25 pairs of males and 17 of 25 pairs of females. There was a distinct difference in the pelage colour between sibling lemmings of both sexes maintained in $6 \mathrm{~L}: 18 \mathrm{D}$ and 20L:4D photoperiods. All males and females in 20L:4D had a dark brown pelage. Nineteen of 33 lemmings in $6 \mathrm{~L}: 18 \mathrm{D}$ were completely white and another 5 were predominantly white with one or more patches of brown hair. The remaining 9 lemmings in $6 \mathrm{~L}: 18 \mathrm{D}$ ranged from dark to light grey in colour. All animals in $6 \mathrm{~L}: 18 \mathrm{D}$ developed bifid or double claws on the third and fourth digits of the forefeet as described by Hansen (1957a), but none of the others did so.

Table 1. Mean ( \pm S.E.M.) body and organ weights of female and male collared lemmings reared in two different photoperiods

\begin{tabular}{|c|c|c|c|}
\hline & \multicolumn{2}{|c|}{ Daily photoperiod } & \multirow[b]{2}{*}{ Significance* } \\
\hline & $6 \mathrm{hr}$ & $20 \mathrm{hr}$ & \\
\hline \multicolumn{4}{|l|}{ Females } \\
\hline No. of animals & 17 & 17 & \\
\hline Initial body wt (g) & $29 \cdot 9 \pm 1 \cdot 6$ & $30 \cdot 2 \pm 1 \cdot 5$ & N.S. \\
\hline Final body wt (g) & $68 \cdot 9 \pm 2 \cdot 6$ & $55 \cdot 6 \pm 2 \cdot 3$ & $P<0.001$ \\
\hline Ovaries (mg) & $3 \cdot 6 \pm 0.4$ & $3 \cdot 7 \pm 0.4$ & N.S. \\
\hline Uterus (mg) & $47 \cdot 0 \pm 5 \cdot 4$ & $53 \cdot 0 \pm 5 \cdot 4$ & N.S. \\
\hline Preputial glands (mg) & $63 \cdot 3 \pm 9 \cdot 1$ & $38 \cdot 2 \pm 4 \cdot 8$ & $P<0.01$ \\
\hline Adrenals (mg) & $10 \cdot 7 \pm 0.7$ & $9 \cdot 9 \pm 0.9$ & N.S. \\
\hline \multicolumn{4}{|l|}{ Males } \\
\hline No. of animais & 16 & 16 & \\
\hline Initial body wt (g) & $27 \cdot 1 \pm 1 \cdot 3$ & $27 \cdot 4 \pm 1 \cdot 3$ & N.S. \\
\hline Final body wt (g) & $67 \cdot 7 \pm 2 \cdot 6$ & $55 \cdot 8 \pm 3 \cdot 0$ & $P<0.005$ \\
\hline Testes (mg) & $138 \cdot 3 \pm 12 \cdot 2$ & $154 \cdot 7 \pm 22 \cdot 3$ & N.S. \\
\hline Seminal vesicles (mg) & $46.6 \pm 7.9$ & $62 \cdot 2 \pm 13 \cdot 2$ & N.S. \\
\hline Preputial glands (mg) & $142 \cdot 8 \pm 20 \cdot 2$ & $119 \cdot 7 \pm 25 \cdot 4$ & N.S. \\
\hline Adrenals (mg) & $11 \cdot 6 \pm 0.6$ & $9 \cdot 6 \pm 0.4$ & $P<0.005$ \\
\hline
\end{tabular}

* Student's $t$ test for paired data. 
Males and females maintained in $6 \mathrm{~L}: 18 \mathrm{D}$ from the age of 19-25 days were significantly heavier after 70 days than their siblings kept in 20L:4D (Table 1). There were no significant differences between the two groups in uterine, ovarian or adrenal weights or in the numbers or sizes of either healthy or atretic Graafian follicles. There were no CL in any ovaries in the two groups. There were no differences in the weights of testes, seminal vesicles or preputial glands of the two groups of males. There were no detectable histological differences in the testes. All males except one in the 6L:18D group and two in the 20L:4D group exhibited active spermatogenesis and spermatozoa in the cauda epididymidis. The mean ( \pm S.E.M.) plasma testosterone level of the $20 \mathrm{~L}: 4 \mathrm{D}$ males $(0 \cdot 78 \pm 0 \cdot 18$ $\mathrm{ng} / \mathrm{ml}$ plasma) was not significantly different from that of the $6 \mathrm{~L}: 18 \mathrm{D}$ males $(0 \cdot 81 \pm 0 \cdot 17 \mathrm{ng} / \mathrm{ml}$ plasma).

Analysis of the body composition (Table 2) of the two groups of males revealed that $6 \mathrm{~L}: 18 \mathrm{D}$ males had significantly heavier lean dry weights (body weight minus water and lipid weights) than their 20L:4D siblings. The fat index (lipid weight/dry lean weight) was significantly greater for the 20L :4D group.

Table 2. Mean ( \pm S.E.M.) body weight, length and composition of male collared lemmings reared in two different photoperiods

\begin{tabular}{|c|c|c|c|}
\hline & \multicolumn{2}{|c|}{ Daily photoperiod } & \multirow[b]{2}{*}{ Significance* } \\
\hline & $6 \mathrm{hr}$ & $20 \mathrm{hr}$ & \\
\hline No. of animals & 16 & 16 & \\
\hline Eviscerated body wt (g) & $5 \mathrm{I} \cdot 7 \pm 2 \cdot 6$ & $44 \cdot 7 \pm 3 \cdot 1$ & $P<0.005$ \\
\hline Final body length (mm) & $129 \cdot 6 \pm 1 \cdot 6$ & $122.1 \pm 1.7$ & $P<0.005$ \\
\hline \multicolumn{4}{|l|}{ Eviscerated carcass composition } \\
\hline No. of animals & 13 & 13 & \\
\hline $\mathrm{H}_{2} \mathrm{O}$ weight $(\mathrm{g})$ & $26 \cdot 54 \pm 1 \cdot 12$ & $21 \cdot 67 \pm 1 \cdot 13$ & $P<0.05$ \\
\hline $\mathrm{H}_{2} \mathrm{O}$ as $\%$ eviscerated body wt & $51 \cdot 7 \pm 1 \cdot 1$ & $48 \cdot 6 \pm 1 \cdot 6$ & $P<0.05$ \\
\hline Lipid weight $(\mathrm{g})$ & $11 \cdot 62 \pm 1 \cdot 14$ & $11.93 \pm 1.54$ & N.S. \\
\hline Lipid as $\%$ of eviscerated body wt & $22 \cdot 0 \pm 1 \cdot 3$ & $24.9 \pm 1.8$ & N.S. \\
\hline Ash weight (g) & $2.21 \pm 0.08$ & $1.87 \pm 0.06$ & $P<0.005$ \\
\hline Ash as $\%$ of eviscerated body wt & $4 \cdot 3 \pm 0 \cdot 1$ & $4 \cdot 3 \pm 0 \cdot 2$ & N.S. \\
\hline Lean dry weight $\uparrow$ & $13.5 \pm 0.65$ & $11 \cdot 1+0.64$ & $P<0.005$ \\
\hline Fat index $\ddagger$ & $0.83 \pm 0.06$ & $1.02 \pm 0.11$ & $P<0.05$ \\
\hline
\end{tabular}

* Student's $t$ test for paired data.

$\dagger$ Eviscerated body wt-(water wt+lipid wt).

$\$$ Lipid wt/lean dry wt.

Table 3. Mean ( \pm S.E.M.) body weights and plasma testosterone levels of adult male collared lemmings before and after maintenance for 10 weeks on two different photoperiods

\begin{tabular}{lccc} 
& \multicolumn{2}{c}{ Daily photoperiod } & \\
\cline { 2 - 3 } & $6 \mathrm{hr}$ & Significance* \\
\hline Body weight (g) & & $20 \mathrm{hr}$ & \\
$\quad$ No. of animals & 11 & 12 & \\
Initial & $65 \cdot 1 \pm 3.3$ & $60.6 \pm 5 \cdot 2$ & N.S. \\
Final & $83.7 \pm 3.6$ & $69.0 \pm 5.4$ & $P<0.05$ \\
Gain & $18.2 \pm 3.5$ & $8.4 \pm 1.9$ & \\
Plasma testosterone & & & \\
(ng/ml plasma) & 8 & 8.02 \\
No. of animals & $0.92 \pm 0.59$ & $0.45 \pm 0.09$ & N.S. \\
Initial & $0.76 \pm 0.23$ & $0.56 \pm 0.17$ & N.S. \\
Final & & & \\
\hline
\end{tabular}

* Student's $t$ test. 


\section{Experiment 2}

Adult males maintained in $6 \mathrm{~L}: 18 \mathrm{D}$ for 10 weeks were significantly heavier than $20 \mathrm{~L}: 4 \mathrm{D}$ males (Table 3). There were no significant differences in the plasma testosterone levels between the two groups either at the beginning or end of the experiment, and there were no significant changes in plasma testosterone levels within the two groups. All males kept in $6 \mathrm{~L}: 18 \mathrm{D}$ exhibited healthy seminiferous tubules undergoing active spermatogenesis and epididymal spermatozoa.

\section{Discussion}

There appear to be distinct species differences in the influence of photoperiod on reproductive function in adult male microtines. Clarke \& Kennedy (1967) showed that wild-caught and laboratoryraised adult male field voles (Microtus agrestis) exhibited a marked regression in testis and seminal vesicle weights, but no change in body weight when they were maintained on $6 \mathrm{~L}: 18 \mathrm{D}$ for 84 days. Spermatogenesis ceased completely in some males. Field studies of this species have shown that, during most winters, adult males became sexually inactive (Brambell \& Hall, 1939; Clarke \& Forsyth, 1964). In a recent study, Roth (1974) concluded that a combination of long photoperiod (20L:4D) and low temperature had a stimulatory effect upon the testes of red-backed voles (Clethrionomys gapperi). Testes of males maintained in a short photoperiod (4L:20D) were only slightly less spermatogenically active than testes of males on $20 \mathrm{~L}: 4 \mathrm{D}$, whereas testes of wintertrapped males were quiescent. Pinter \& Negus (1965) showed that males of Microtus montanus were fertile when maintained in $6 \mathrm{~L}: 18 \mathrm{D}$. In the present study there was no detectable effect of short photoperiod on the reproductive state of adult male lemmings and winter breeding in this species has been reported (Sutton \& Hamilton, 1932; Krebs, 1964; MacLean et al., 1974).

In spite of the differences in body weight observed in the present study, male and female lemmings in both photoperiods appeared to have attained sexual maturity by the end of the 70-day test period as indicated by epididymal spermatozoa in males and Graafian follicles in females. In our laboratory, a small number of males maintained in 18L:6D exhibit epididymal spermatozoa at 55 days of age but most do not do so until 90 days of age. The mean age at first vaginal perforation in this species is 42 days (Hasler \& Banks, 1975b), but few laboratory females become pregnant before 60-70 days of age. The absence of vaginal perforation in this species, however, does not necessarily indicate that sexual maturity has not been achieved, because without adequate exteroceptive stimulation many adult females remain imperforate (Hasler \& Banks, 1975c). The absence of CL in both groups of females in the present study is consistent with the previous finding that ovulation is induced by copulation (Hasler, Dziuk \& Banks, 1974). The design of this experiment precluded the determination of whether photoperiod influenced the rate of sexual maturation in either sex. It is clear, however, that a photoperiod of $6 \mathrm{~L}: 18 \mathrm{D}$ does not prevent the attainment of fertility in this species.

The influence of photoperiod on sexual maturation appears to be much more profound in the vole $M$. agrestis than in Dicrostonyx. Testes and seminal vesicles were at least 3 times heavier in young male voles exposed for 84 days to $16 \mathrm{~L}: 8 \mathrm{D}$ compared to those in $6 \mathrm{~L}: 18 \mathrm{D}$ (Clarke \& Kennedy, 1967). Similarly, females in 16L:8D had ovaries and uteri which were considerably heavier than those of 6L:18D females. Breed \& Clarke (1970) demonstrated that $6 \mathrm{~L}: 18 \mathrm{D}$ delayed but did not prevent ovarian development in $M$. agrestis. Thibault et al. (1966) reported that photoperiods as short as $5 \mathrm{hr}$ delayed but did not prevent sexual maturation in males and females of $M$. arvalis. Lecyk (1963), however, reported that a $7 \mathrm{hr}$ photoperiod completely inhibited the attainment of puberty in males of the same species. These voles were from a different population from those studied by Thibault et al. (1966). Thus, the sensitivity of the two populations to environmental stimuli may have varied. Clarke \& Kennedy (1967) found a large degree of heterogeneity in the susceptibility of individual voles to different photoperiods and we also found a large range of variation in the organ weights of animals within treatment groups. In the present study, body weights of males and females maintained from weaning in 6L:18D were heavier at the end of 70 days than those in $20 \mathrm{~L}: 4 \mathrm{D}$. The body composition of females and adult males was not examined but $6 \mathrm{~L}: 18 \mathrm{D}$ juvenile males were longer and exhibited heavier whole body and lean dry weights than the 20L:4D males. The 
heavier lean dry weights and ash weights indicate that the $6 \mathrm{~L}: 18 \mathrm{D}$ males were composed of more bone and protein and thus had undergone greater overall growth than the 20L:4D males.

We cannot explain why lemmings grew more on $6 \mathrm{~L}: 18 \mathrm{D}$. It may be related to activity of this species. We did not measure activity patterns or food intake, but several field studies have indicated that Dicrostonyx is most active at night (Bee \& Hall, 1956; Andrews, 1970) and Hansen (1957b) found that shortening photoperiod did not change the number of daily activity periods but did significantly increase the mean duration of the activity periods.

Clarke \& Kennedy (1967), however, reported that young male and female $M$. agrestis raised in 16L:8D were heavier than those in $6 \mathrm{~L}: 18 \mathrm{D}$, although body composition was not determined. Similarly, the weights of female $M$. montanus maintained in constant dark were considerably lighter than females maintained in $18 \mathrm{hr}$ light (Vaughan, Vaughan \& Reiter, 1973). Roth (1974) found no difference in body weights of adult male red-backed voles maintained in 4L:20D and 20L:4D.

Apart from D. groenlandicus, we do not know of any other mammal in which growth is greater in short than long photoperiods. Sorrentino, Reiter \& Schalch (1971) observed that young male rats deprived of light by blinding exhibited retarded body growth and reduced pituitary levels of growth hormone, and concluded that the pineal gland was involved. The present study demonstrated that $6 \mathrm{~L}: 18 \mathrm{D}$ leads to the development of double or bifid claws in all collared lemmings and the moult to a white pelage in some. We are unaware of any studies on the adaptive significance of either the bifid claws or white pelage in this species. In the present study, a total of $24 / 33$ males and females reared in $6 \mathrm{~L}: 18 \mathrm{D}$ from weaning moulted to a predominantly white pelage. Previous observations (Hasler, 1974) on the pelage of adults ( $>120$ days of age) maintained in $6 \mathrm{~L}: 18 \mathrm{D}$, combined with those from this study, indicated that only $8 / 29$ adults moulted to a predominantly white coat. LeBlanc (1956) reported that only $50 \%$ of wild-trapped D. groenlandicus moulted to white in the fall. Hansen (1959) commented that subadult and immature collared lemmings were less variable than adults in pelage colour and reported that young lemmings moulted from the immature to the subadult pelage at 27-30 days of age. Thus, the lemmings raised from weaning in the present study may have undergone this moult soon after they were introduced to the experimental photoperiods but they did not start the moult to white until approximately 40 days of age. The adults, of various ages, may have exhibited a lower response of moulting to white than the juveniles because their moult cycles were not synchronized (see Ling, 1970, for review of moulting in mammals). There was an apparent relationship between body weight and pelage colour of weanling lemmings raised in $6 \mathrm{~L}: 18 \mathrm{D}$. Only one of the 24/33 animals which became white in $6 \mathrm{~L}: 18 \mathrm{D}$ had a lighter body weight than its sibling in 20L:4D. Of the $96 \mathrm{~L}: 18 \mathrm{D}$ animals which did not turn white, 5 were lighter in weight than their siblings in 20L:4D ( $P<0.01, \chi^{2}$ analysis). Thus factors associated with the moult to a white coat in short photoperiod may be related to the observed increase in growth.

We thank Dr A. V. Nalbandov and Dr G. O. Batzli for the generous use of their laboratory facilities, and Dr B. Caldwell, Yale University School of Medicine, for the testosterone antiserum. This research was supported by USPHSMH 10175 and NSFGB 41721 grants to E.M.B.

\section{References}

ANDREwS, R.V. (1970) Circadian variations in adrenal secretion of lemmings, voles and mice. Acta endocr., Copenh. 65, 645-649.

BeE, J.W. \& HALL, E.R. (1956) Mammais of northern Alaska on the arctic slope. Univ. Kans. Publs Mus. nat. Hist. 8, 1-309.

Brambell, F.W.R. \& Hall, K. (1939) Reproduction in the field vole, Microtus agrestis hirtus Bellamy. Proc. zool. Soc. Lond. 109, 133-138.

Breed, W.G. \& Clarke, J.R. (1970) Effect of photoperiod on ovarian function in the vole, Microtus agrestis. J. Reprod. Fert. 23, 189-192.
Brooxs, R.J. (1970) Ecology and acoustic behavior of the collared lemming, Dicrostonyx groenlandicus (Traill). Ph.D. thesis, University of Illinois, Urbana.

Christian, J.J. (1971) Population density and reproductive efficiency. Biol. Reprod. 4, 248-294.

Clarke, J.R. \& Forsyth, I.A. (1964) Seasonal changes in the gonads and accessory reproductive organs of the vole (Microtus agrestis). Gen. comp. Endocr. 4, 233-242.

Clarke, J.R. \& Kennedy, J.P. (1967) Effect of light and temperature upon gonad activity in the vole (Microtus agrestis), Gen, comp. Endocr, 8, 474-488. 
Falvo, R.E., Buhl, A. \& Nalbandov, A.V. (1974) Testosterone concentration in the peripheral plasma of androgenized females and in the estrous cycle of normal female rats. Endocrinology 95, 26-29.

HALl, E.R. \& Kelson, K.R. (1959) The Mammals of North America, Vol. 2. The Ronald Press Co., New York.

Hansen, R.M. (1957a) Remarks on the bifid claws of varying lemmings. $J$. Mammal. 38, 127-128.

HANSEN, R.M. (1957b) Influence of daylength on activity of the varying lemming. J. Mammal. 38, 218-223.

HANSEN, R.M. (1959) Aspects of coat color in young varying lemmings. J. Mammal. 40, 205-213.

HASLER, J.F. (1974) Reproduction of the collared lemming, Dicrostonyx groenlandicus. Ph.D. thesis, University of Illinois, Urbana.

HASLER, J.F. \& BANKs, E.M. (1975a) Reproductive performance and growth in captive collared lemmings (Dicrostonyx groenlandicus). Can.J. Zool. 53, $777-787$.

HASLER, J.F. \& BANKS, E.M. (1975b) The influence of mature males on sexual maturation in female collared lemmings (Dicrostonyx groenlandicus). $J$. Reprod. Fert. 42, 583-586.

HASLER, J.F. \& BANKS, E.M. (1975c) The influence of exteroceptive factors on the estrous cycle of the collared lemming (Dicrostonyx groenlandicus). Biol. Reprod. 12, 647-656.

Hasler, J.F., DziUk, P.J. \& Banks, E.M. (1974) Ovulation and related phenomena in the collared lemming (Dicrostonyx groenlandicus). J. Reprod. Fert. 38, 21-28.

Kalela, O. (1957) Regulation of reproductive rate in subarctic populations of the vole Clethrionomys rufocanus (Sund.). Annls Acad. sci. fenn., Ser. A4 $34,1-60$.

KeLLER, B.L. \& KREBS, C.J. (1970) Microtus population biology. III. Reproduction changes in fluctuating populations of Microtus ochrogaster and Microtus pennsylvanicus in southern Indiana, 1965-67. Ecol. Monogr. 40, 263-294.

KReBS, C.J. (1964) The lemming cycle at Baker Lake, Northwest Territories, during 1959-62. Arctic 15, 1-104.
LeBLANC, J.S. (1956) Rearing of lemmings at Ft. Churchill, Manitoba. J. Mammal. 37, 447-448.

LECYK, M. (1963) The effect of short daylength on sexual maturation in young individuals of the vole Microtus arvalis. Zool. Pol. 13, 77-86.

LING, J.L. (1970) Pelage and molting in wild mammals with special reference to aquatic forms. $Q$. Rev. Biol. 45, 16-54.

Maclean, S.F., JR, Fitzgerald, B.M. \& Pitelka, F.A. (1974) Population cycles in arctic lemmings: winter reproduction and predation by weasels. Arctic Alpine Res. 6, 1-12.

Pinter, A.J. \& Negus, N.C. (1965) Effects of nutrition and photoperiod on reproductive physiology of Microtus montanus. Am. J. Physiol. 208, 633638.

RoTh, R.R. (1974) The effect of temperature and light combinations upon the gonads of male red-back voles. Biol. Reprod. 10, 309-314.

SHELFORD, V.E. (1943) The abundance of the collared lemming (Dicrostonyx groenlandicus (TR.) VAR. richardsoni Mer.) in the Churchill area, 1929-1940. Ecology 24, 472-484.

SorRentino, S., JR, Reiter, R.J. \& Schalch, D.S. (1971) Pineal regulation of growth hormone synthesis and release in blinded and blinded-anosmic male rats. Neuroendocrinology 7, 210-218.

Sutton, G.M. \& Hamizton, W.J. (1932) The exploration of Southhampton Island, Hudson Bay. Part II, Sect. 1. The mammals of Southhampton Island. Mem. Carneg. Mus. 12, 1-111.

Thibault, C., Courot, M., Martinet, L., Mauleon, P., du Mesnil du Buisson, F., Ortavant, P. Pelletier, J. \& Signoret, J.P. (1966) Regulation of breeding season and oestrous cycles by light and external stimuli in some mammals. J. Anim. Sci. 25 , 119-142, (Suppl.).

United States Naval Observatory (1973) The American Ephemeris and Nautical Almanac. U.S. Government Printing Office, Washington, D.C.

Vaughan, M.K., Vaughan, G.M. \& Reiter, R.J. (1973) Effect of ovariectomy and constant dark on the weight of reproductive and certain other organs in the female vole, Microtus montanus. J. Reprod. Fert. 32, 9-14. 